\title{
Integrating the Beauty of Herbs Zingiberaceae into Science Learning Through Nature of Science Within the Active Learning Approach
}

\author{
A. Widowati ${ }^{1 *}$, Sri Atun ${ }^{2}$, IGP. Suryadarma ${ }^{3}$ \\ ${ }^{I}$ Science Education Department, Faculty Mathematics and Natural Science, Yogyakarta State University \\ ${ }^{2}$ Chemistry Department, Faculty Mathematics and Natural Science, Yogyakarta State University \\ ${ }^{3}$ Biology Education Department, Faculty Mathematics and Natural Science, Yogyakarta State University \\ *Corresponding author. Email: asri_widowati@uny.ac.id
}

\begin{abstract}
Nature and its phenomenon are objects of natural w learning. Learning of natural science helps students to understand aspects of life. One of the natural potentials that can be used as an object of science learning is the charm of Zingiberaceae herbs, like the one popular of plant's family using as herbs. This exploration is to answer the question "how to use the beauty of Zingiberaceae herbs as natural science learning object?". Based on the requirements of learning resources, the beauty of Zingiberaceae herbs can be utilized for science learning on Plant Structure-Functions, Plant Biodiversity, Substance Change, and Mixed Separation. Active learning with NoS content can be carried out by utilizing the beauty of Zingiberaceae herbs.
\end{abstract}

Keywords: Science Learning, Nature of Science, Active Learning Approach, Zingiberaceae.

\section{INTRODUCTION}

Science learning helps students to understand the aspects that are around them, both natural environment application of science. Natural science learning to begin to form concepts through exploration or exploration experiment. But there are still some teachers still consider that science is nothing more than a presentation with a blackboard or whiteboard, boast of scientific jargon, copying concepts from science books. Some of the others have developed proposals. Fill questions for students to investigate. Then questions that arise, how to use natural objects and its phenomena as science learning materials?

Learning science is essential for interacting students with objects, then the contextually is also demanded so there is no gap between science and everyday life. Johnson [1] suggests that contextual learning is a learning system based on the philosophy that students can absorb lessons if: (1) students can take meaning from academic materials and school assignments; (2) students can associate new information with initial knowledge and experience. Based on these, it can be understood that contextual learning invites students to associate what is learned and the meaning of everyday life.

The basics of science can found in various events daily. But order the basics can be implemented students need to be held to finish a thorough one. Teaching science will deepen the understanding of students about natural phenomena, too, will create critical, logical, and systematic in a way of thinking, and this stuff is a huge influence on attitudes and actions. The understanding obtained by students from learning will make that the students can realize and appreciate the importance of the natural surroundings for education.

Nature provides so many phenomena of objects and events for science learning. Such potential in real terms has not been utilized with well. Widowati, et.al state that one problem of natural sciences learning is poorly to optimize nature as learning resources [2]. Even though the natural surroundings can be used for learning media cheap, attractive, and able to provide concrete experiences for students. The utilization of the environment for science learning depends on the willingness, ability, and creativity of the teacher. One of 
the natural objects that can be used in learning science is herbs Zingiberaceae, like the one popular of plant's family using as herbs or traditional medicine.

Besides natural objects, science learning is also important to enter school and participate actively. One of the efforts is by integrating the Nature of Science (NoS) content into active approach learning. Widowati, et.al. [3] state that the effort by helping students develop an information conception of the NoS and apply an inquiry approach can develop science literacy. Teachers need to understand the essence of science comprehensively and capably communicate this understanding effectively to students through various strategies or lessons approach. The active learning approach is based on constructivism and can provide an authentic learning experience. The results of this study indicate that the application active learning approach in science learning has a positive effect on cognitive outcomes, processing abilities, and attitudes [4].

\section{DISCUSSION}

\subsection{Why is it important to use herbs as a natural science learning object?}

Natural science learning that interacts with students with nature will create authentic and meaningful science learning. Learning is meaningful to develop scientific skills and the ability to think creatively so that it can solve various problems that exist. Students need to be facilitated in learning to practice scientific skills and creative thinking skills by raising learning patterns and teaching students how to solve them. Of course, teachers need to have skills in carrying out authentic learning. It is also necessary to have the skills to create instructional media that can support the implementation of authentic learning.

One of the natural potentials is in the form of Zingiberaceae herbs. The choice of the object is certainly reasonable. The beauty of herbs needs to be preserved because the longer it is fading, and it is feared that the future will disappear. This can be anticipated by utilizing "Beauty of Herbs Zingiberaceae" in science learning. The science learning that is carried out can grow environmental awareness to help education to face the challenges of the crisis environment in the 21 st century with "linking knowledge to action". The traditional medicinal plants are almost extinct so that whenever needed, it is difficult to get them [5]. Herbs Zingiberaceae as the most popular traditional medicinal plant, for example, ginger, turmeric, curcuma, etc. The theme of herbs is a contextual issue, considering that herbs are a cultural heritage of the Indonesian people but the younger generation is not familiar with herbs well.

\subsection{How are the steps to developing the Beauty of Herbs Zingiberaceae as a science learning object?}

For the utilization of the surrounding environment that is held can effectively lead to the achievement of the concepts being learned, the teacher must be able to organize and guide student activities. The teacher's activities in utilizing the natural surroundings as a source of natural science learning as an aspect of behavior will be influenced by their perceptions and attitudes towards their professional duties, as well as perceptions of the potential of natural objects around them to support learning activities. Thus the teacher will determine his perceptions and attitudes towards the potential of natural objects around him. Furthermore, perceptions or attitudes that are owned will determine the behavior of teachers in carrying out professional tasks, including the behavior of utilizing natural objects around in science learning.

Utilization of natural potential in the form of herbs from the Zingiberaceae family and their rhizomes, which can be used to teach science with the steps that are developed [6]. The steps for utilizing the potential of Zingiberaceae herbal enchantment as science teaching materials are as follows.

\subsubsection{Clarity of potential}

The clarity of potential is determined by several objects and problems that can be revealed. Objects used in this study were Zingiberaceae plants as herbs. The objects contained problems that could be revealed in an activity of learning. The question raised was "Which part of the plant is modified into the rhizome?", "What are the differences between plants of the member Zingiberaceae family and non-Zingberaceae?", "What changes occur during the manufacture of herbal medicine from Zingberaceae extract?".

\subsubsection{Consistency with learning objectives}

Based on the results of the analysis of curriculum 2013 revision for the lesson of natural sciences, several topics can be studied using the beauty of Zingiberaceae such as Plant Structure-Functions, Plant Biodiversity, Substance Change, and Mixed Separation. The competence of natural sciences lessons can be mapped as shown in Table 1. 
Table 1. Map of natural science competences based on curriculum 2013 revision

\begin{tabular}{|c|c|c|c|}
\hline \multirow[b]{2}{*}{ Aspect } & \multicolumn{3}{|c|}{ The Topic in Science Lesson } \\
\hline & Structure and Function & Biodiversity & $\begin{array}{c}\text { Change of Matter and Mixed } \\
\text { Separation }\end{array}$ \\
\hline $\begin{array}{l}\text { Basic } \\
\text { Competence }\end{array}$ & $\begin{array}{l}\text { Grade } 8^{\text {th }} \\
\text { 3.4.Analyzing structural } \\
\text { linkages } \\
\text { plant tissue and its functions, } \\
\text { as well as technology inspired } \\
\text { by } \\
\text { plant structure } \\
4.4 \text { Presenting the work of the } \\
\text { results } \\
\text { search for multiple sources } \\
\text { information about that } \\
\text { technology inspired by observations } \\
\text { plant structure }\end{array}$ & $\begin{array}{l}\text { Grade } 7^{\text {th }} \\
\text { 3.2. Classifying living things } \\
\text { and objects based on } \\
\text { characteristics } \\
\text { being observed } \\
\text { 4.2. Present results } \\
\text { classification of creatures } \\
\text { life and objects on } \\
\text { surrounding environment } \\
\text { based on that characteristic } \\
\text { observed }\end{array}$ & $\begin{array}{l}\text { Grade } 7^{\text {th }} \\
\text { 3.3. Describe the concept of } \\
\text { mix and } \\
\text { single substances (elements } \\
\text { and compounds), properties } \\
\text { physics and chemistry, physics } \\
\text { change } \\
\text { and chemistry in life } \\
\text { daily } \\
4.3 \text {. Presenting the results of } \\
\text { the investigation } \\
\text { or works on the properties of } \\
\text { solutions, } \\
\text { physics change and change } \\
\text { chemistry, or the separation of } \\
\text { a mixture }\end{array}$ \\
\hline $\begin{array}{l}\text { Learning } \\
\text { Objectives }\end{array}$ & $\begin{array}{l}\text { 1. } \begin{array}{l}\text { Identifying the } \\
\text { morphological } \\
\text { characteristics of the } \\
\text { rhizomes, roots, stems, } \\
\text { and leaves of the } \\
\text { Zingiberaceae family } \\
\text { plants. } \\
\text { Identifying the anatomical } \\
\text { features of the rhizomes, } \\
\text { roots, stems, and leaves } \\
\text { of the Zingiberaceae } \\
\text { family plants. } \\
\text { Comparing rhizome } \\
\text { characteristics with the } \\
\text { roots, stems, and leaves } \\
\text { of plants of the } \\
\text { Zingiberaceae family. } \\
\text { Finding the structure of } \\
\text { plant origin that was } \\
\text { modified into plant } \\
\text { rhizomes of the } \\
\text { Zingiberaceae family. } \\
\text { Knowing the content of } \\
\text { organic compounds of } \\
\text { several plant rhizomes of } \\
\text { the Zingiberaceae family }\end{array}\end{array}$ & 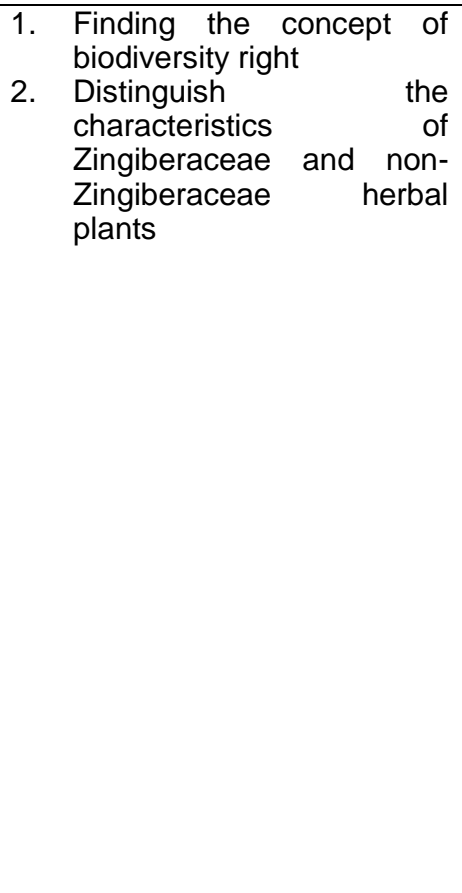 & $\begin{array}{l}\text { 1. Identifying the phenomena } \\
\text { of physical changes that } \\
\text { occur when making } \\
\text { traditional herbal medicine } \\
\text { from Zingiberaceae } \\
\text { rhizome extract. } \\
\text { 2. ldentifying } \\
\text { phenomenon of chemical } \\
\text { changes that occur when } \\
\text { making traditional herbal } \\
\text { medicine from } \\
\text { Zingiberaceae rhizome } \\
\text { extract rang in the } \\
\text { Finding the principle in the } \\
\text { mechanism of separation } \\
\text { of the mixture in 'jamu' } \\
\text { making from } \\
\text { Zingiberaceae's rhizome } \\
\text { extract. }\end{array}$ \\
\hline $\begin{array}{l}\text { Scientific } \\
\text { Problem }\end{array}$ & $\begin{array}{l}\text { Which part of the plant is } \\
\text { modified into the rhizome? }\end{array}$ & $\begin{array}{l}\text { What are the differences } \\
\text { between the plant of the } \\
\text { member Zingiberaceae family } \\
\text { and non-Zingiberaceae? }\end{array}$ & $\begin{array}{l}\text { What changes occur during the } \\
\text { manufacture of herbal } \\
\text { medicine from Zingberaceae } \\
\text { extract? }\end{array}$ \\
\hline Material & $\begin{array}{l}\text { Plants of Zingiberaceae family } \\
\text { Zingiberaceae plant parts (leaf, } \\
\text { root, stem, rhizome), } \\
\text { Microscope, Lup, Object glass } \\
\text { and cover glass, Pippete, } \\
\text { Razorblade, Water }\end{array}$ & $\begin{array}{l}\text { plants coded } \mathrm{A}, \mathrm{B}, \mathrm{C}, \mathrm{D}, \mathrm{E} \\
\text { (Zingiberaceae } \\
\text { Zingiberaceae) }\end{array}$ & $\begin{array}{l}\text { Zingiberaceae's rhizome, } \\
\text { 'jamu' making equipment } \\
\text { (blender, frying pan, filter, } \\
\text { stove, spoon,etc.) }\end{array}$ \\
\hline
\end{tabular}




\subsubsection{Clarity of targets}

Targets that should be aimed are:

a. Targets of observation: structure morphology and anatomy the parts of plant Zingiberaceae and functions, especially leaf, root, stem, and rhizome; the similarities and differences structure morphology the parts of non-Zingiberaceae, a phenomenon that occurs when making herbal medicine.

b. Targets of allocation (subjects) are students of junior high school.

\subsubsection{Clarity of revealed information}

Information forms that want to be revealed are: (a) structure of leaf, root, stem, rhizome (morphology and anatomy), (b) biodiversity between non-Zingiberaceae and Zingiberaceae plant; (c) physical and chemical change of matter; (d) mixed separation when making herbal medicine from Zingberaceae's rhizome.

\subsubsection{Clarity of exploration guidance}

Exploration guidance that is achieved in the exploration of morphologic and anatomic structures of Zingiberaceae plant parts (leaf, stem, root, and rhizome), in the investigation of the biodiversity between Zingiberaceae and non-Zingiberaceae group, in observation the process of making herbal medicine from Zingiberaceae's rhizome.

\subsubsection{Clarity of expected achievement}

a. Cognitive achievements obtained are: knowledge on structure and function of the plant, biodiversity, physical and chemical change of matter, mixed separation (filtration, recrystallization) b. Expected affective achievements are: students can develop sensitivity to the environment, careful attitude in observing, accuracy to read data, cooperating in the discussion, responsible, receiving and appreciating opinions of others, critical of insulting problems of society.

c. Expected psychomotor achievements such as: observing, interpreting data, making conclusions.

\subsection{How are the steps learning to use the Beauty of Herbs Zingiberaceae through NoS within Active Learning Approach?}

Integrating the NoS content in science learning requires an in-depth analysis of the suitability of integrated learning activities and the NoS content and considering the more learning time if more and more NoS content is integrated. The integration of NoS content is carried out explicitly and reflectively and scientific investigation into science content is a means of rapidly developing scientific literacy [7]. The determination of the integration of the NoS content in science learning or science teaching materials refers to the characteristics of the material and the topic of the experiment. This is by the opinion of Lederman \& Lederman [8] that all aspects of NoS do not have to appear in every learning activity, but focus on several aspects of NoS that fit the learning material better.

Therefore, the NoS content that is inserted in each learning activity on the Natural Science teaching materials varies between the Science learning activities of each science material being learned. The following is an example of an NoS active learning scenario for biodiversity material between Zingiberaceae plants and between Zingiberaceae and non-Zingiberaceae plants.

Table 2. Learning scenarios with NoS within an active approach in "Biodiversity" topic

\begin{tabular}{|c|c|c|}
\hline Learning Activity & $\begin{array}{l}\text { Content of Nature } \\
\text { of Science (NoS) }\end{array}$ & $\begin{array}{l}\text { Time } \\
\text { Allocation } \\
\text { (minute) }\end{array}$ \\
\hline $\begin{array}{l}\text { Observing } \\
\text { The teacher brought various kinds of herbs from Zingiberaceae and not } \\
\text { Zingiberaceae } \\
\text { The teacher invites students to observe one by one of the parts shown by the } \\
\text { teacher and asks students to temporarily record their observations on paper }\end{array}$ & $\begin{array}{l}\text { Science is based on } \\
\text { empirical evidence }\end{array}$ & 5 \\
\hline $\begin{array}{l}\text { Asking } \\
\text { The teacher asks students to ask about the plants that the teacher brought based } \\
\text { on the observations. } \\
\text { The expected questions arise: } \\
\text { 1. What is the difference between rhizomes? } \\
\text { 2. Based on what can the plants be grouped? } \\
\text { 3. What are the benefits of these various rhizomes for health? }\end{array}$ & & 5 \\
\hline
\end{tabular}




\begin{tabular}{|c|c|c|}
\hline Learning Activity & $\begin{array}{l}\text { Content of Nature } \\
\text { of Science (NoS) }\end{array}$ & $\begin{array}{l}\text { Time } \\
\text { Allocation } \\
\text { (minute) }\end{array}$ \\
\hline $\begin{array}{l}\text { Doing Experiments or Observations } \\
\text { The teacher asks students to carry out investigations by observing the differences } \\
\text { and similarities between plants and among rhizome plants morphologically } \\
\text { The teacher asks students to explore the organic compounds contained in the } \\
\text { natural ingredients of the Zingiberaceae plant's rhizomes and the uses of the } \\
\text { Zingiberaceae herbal plant rhizomes for health by using references }\end{array}$ & $\begin{array}{l}\text { The scientific } \\
\text { method is a method } \\
\text { used in science to } \\
\text { solve problems } \\
\text { Science is based on } \\
\text { empirical evidence }\end{array}$ & 15 \\
\hline $\begin{array}{l}\text { Reasoning or Associating } \\
\text { The teacher asks students to solve discussion questions } \\
\text { The teacher asks the student group representatives to present the results of the } \\
\text { group discussion }\end{array}$ & \multirow{2}{*}{$\begin{array}{c}\text { Science is a human } \\
\text { endeavor } \\
\text { Scientific products } \\
\text { in the form of facts, } \\
\text { concepts, } \\
\text { generalizations, } \\
\text { principles, theories, } \\
\text { and laws }\end{array}$} & \\
\hline $\begin{array}{l}\text { Making a conclusion } \\
\text { The teacher asks students to make a conclusion }\end{array}$ & & \\
\hline $\begin{array}{l}\text { Communicating } \\
\text { The teacher asks students to reflect on what students do after learning science } \\
\text { about rhizomes and their properties and the results of the identification of acid- } \\
\text { base properties in plant rhizomes of the Zingiberaceae family. }\end{array}$ & & 5 \\
\hline
\end{tabular}

Furthermore, based on the learning design, so that it can be implemented optimally, it requires teaching materials. In this case, the teaching materials being developed are in the form of a science module or students worksheet. The description of examples of investigation activities is as follows that modification from [9].

\section{Activity Objectives:}

\section{What are the special features of the "Zingiberaceae" group?}

Through this investigation, you are expected to find the concept of biodiversity correctly

\section{Introduction}

We will study the biodiversity between herbs and intra-herbs, especially the Zingiberaceae family.

When you look at the rhizomes of a plant, for example, turmeric, ginger, curcuma. Can you tell the difference? If you can, how do you differentiate between turmeric, ginger, and curcuma rhizomes?

If what you find is not the rhizome, can you tell which is the curcuma plant, which is the ginger plant? What is the cause?

In this activity, you will investigate how to distinguish between ginger, turmeric, and curcuma if there are no rhizomes? Pay attention to the following crop pictures! 


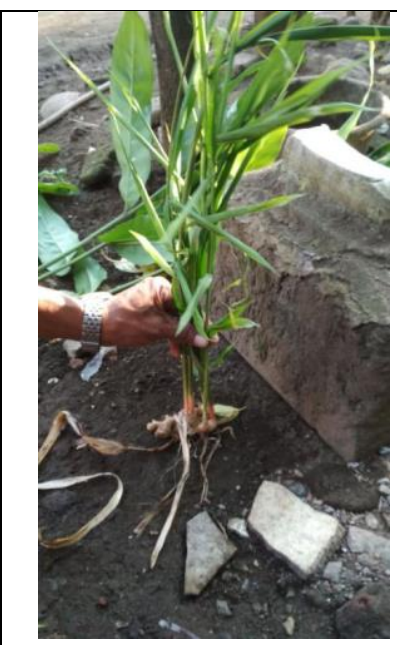

Figure 1. Plant coded A

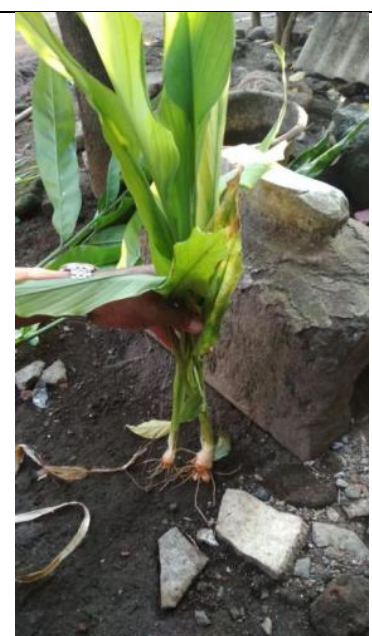

Figure 2. Plant coded B

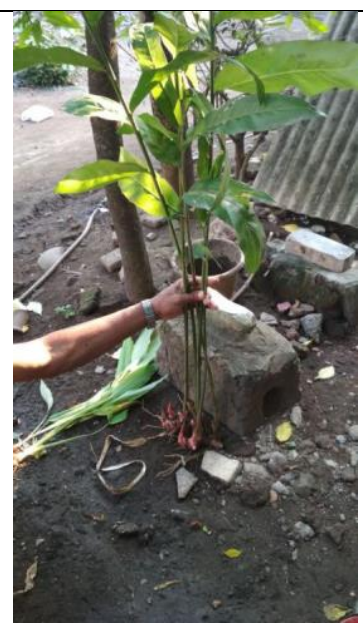

Figure 3. Plant coded C

\section{Investigation Method}

The method you will use to gather empirical evidence for this investigation is observation or observation. What are the things that you must observe?

1. Form the strands, leaf edges

2. The color of the stem and the aroma

3. Root form

4. The shape, color, and smell of the rhizome

The Materials:

Plants coded A, B, C, D, E

Lup

\section{The steps of the investigation}

NoS: The scientific method is a method used in science to solve problems

The steps of investigation to tind the answer the special character of the Zingiberaceae plant

\section{NoS: Science is based on empirical evidence}

4) Identify the special characteristics of the group that you consider to be the Zingiberaceae family. Compare with references, then write down the data from your observations in the table.

The steps of the investigation are:

1) Pay attention to the five plants provided.

2) Observe the leaves, stems, roots in terms of certain parameters, including the presence or absence of rhizomes

3) Identify the five plants, which one is a group, and which is not! Give a checklist in the appropriate column. Determine the basis for your grouping.

\section{NoS: Science is based on empirical evidence}

Work steps 2, 3, and 4 aim to gather empirical evidence.

5) Identify the differences between plant members of the Zingiberaceae family. Write down your observation data in the table can you guess the name of the plant? When viewed from the aspect of their chemical structure, are the plants of the Zingiberaceae family also different? (may open references and internet exploration) 


\section{CONCLUSION}

Based on this discussion, it can be concluded that:

1. Based on the requirements of learning resources which include clarity of potential, clarity of objectives, clarity of information disclosed, clarity of exploration guidelines, and clarity of expected acquisition, the beauty of Zingiberaceae herbs can be utilized for science learning on Plant StructureFunctions, Plant Biodiversity, Substance Change, and Mixed Separation.

2. Active learning with NoS content can be carried out by utilizing the beauty of Zingiberaceae herbs by conducting in-depth analysis regarding the suitability of integrated learning activities and NoS content and considering learning time.

\section{REFERENCES}

[1] Johnson E B 2006 Contextual Teaching and Learning (California: Corwin Press Inc)

[2] Widowati A Juli Astono Agus Purwanto 2014 Influence of Frequency Natural Grasshoppers Sounds To Leaf Chlorophyll Content Teak (Tectona grandis) And Peanut (Arachis hypogaea) As Natural Science Learning Resources Proceeding of International Conference On Research Implementation And Education Of Mathematics And Sciences 2014 (Yogyakarta: FMIPA Yogyakarta State University)

[3] Widowati A Widodo E Anjarsari P and Setuju 2017 The Development Of Scientific Literacy Through Nature Of Science (Nos) Within InquiryBased Learning Approach Journal of Physics: Conference Series 909012067 doi:10.1088/17426596/909/1/012067

[4] Ergul R Yeter S Sevgül Çalu, Zehra Özd Leku G Meral A 2011 The Effect Of Inquiry-Based Science Teaching On Elementary School Students' Science Process Skills And Science Attitudes [versi elektronik]. Bulgarian Journal of Science and Education Policy (BJSEP) 5(1) Download from: http://bjsep.org/getfile.php?id=88, 11 November 2014 p48

[5] Wakidi 2003 Pemasyarakatan Tanaman Obat Keluarga "TOGA” Untuk Mendukung Penggunaan Sendiri "Self Medication" (Medan: Bagian Farmasi Kedokteran Universitas Sumatera Utara)

[6] Suhardi 2012 Pengembangan Sumber Belajar Biologi (Yogyakarta: UNY Press)
[7] Lederman N G Lederman J S and Antink A (2013). Nature of science and scientific inquiry as contexts for the learning of science and achievement of scientific literacy. International Journal of Education in Mathematics, Science and Technology, 1(3), 138-147.

[8] Lederman N G and Lederman J S 2004 Revising Instruction To Teach Nature Of Science: Modifying Activities To Enhance Student Understanding Of Science The Science Teacher 71(9) 36-39.

[9] Widowati A 2019 Pesona Herbal Zingiberaceae Modul IPA (Yogyakarta: PPs UNY). 